\title{
Proline is not useful as a chemical probe to measure nitrosation in the gastrointestinal tract of patients with gastric disorders characterised by anacidic conditions
}

\author{
B ADAM, P SCHLAG, P FRIEDL, R PREUSSMANN, AND G EISENBRAND
}

From the Institute of Toxicology and Chemotherapy, German Cancer Research Centre, Heidelberg, FRG, Section of Surgical Oncology, University of Heidelberg, Heidelberg, FRG, and Department of Food Chemistry and Environmental Toxicology, University of Kaiserslautern, Kaiserslautern, FRG

SUMMARY Aspirated fasting gastric juice from patients with lesions of the gastrointestinal tract and from healthy controls was analysed for nitrite before and after (30, 90, and $240 \mathrm{~min})$ oral administration of $200 \mathrm{mg}$ nitrate. Wilcoxon's rank-sum tests showed no significant differences in fasting gastric juice nitrite concentrations between healthy controls and patients after proximal gastral vagotomy or with gastric/duodenal ulcer (median $\leq 0.7 \mathrm{ppm} \mathrm{NO}_{2}^{-}$) and only moderate increases after nitrate administration. Chronic atrophic gastritis patients and patients with Billroth I or II gastric resections showed median concentrations of 2 ppm $\mathrm{NO}_{2}^{-}$which increased to $20 \mathrm{ppm}$ (up to $200 \mathrm{ppm}$ in one Billroth II patient) after administration of nitrate. Endogenous formation of $\mathrm{N}$-nitrosoproline using the NPRO-test was determined in two groups with low (healthy control and proximal gastral vagotomy patients) and high (Billroth I and II patients) gastric nitrite concentrations. After $12 \mathrm{~h}$ fasting, $200 \mathrm{mg}$ nitrate was orally administered, followed $30 \mathrm{~min}$ later by $\mathbf{5 0 0} \mathrm{mg}$ L-proline. Endogenously formed $\mathrm{N}$-nitrosoproline which is quantitatively excreted in urine was determined in urine over the following 24 hours. In over $80 \%$ of the urine samples collected from Billroth I and II patients no detectable NPRO was found whilst in over $85 \%$ of the healthy controls and proximal gastral vagotomy patients up to $33.5 \mu \mathrm{g}$ NPRO was detected. In vitro nitrosation kinetics showed that at gastric $\mathrm{pH}>4$ present in both, patients with Billroth I and II resections and with chronic atrophic gastritis, nitrosation of proline does not occur. As alternative chemical probes for quantifying potential endogenous nitrosation in hypoacidic patients the methyl and ethyl esters of proline were investigated. In vivo nitrosation of these two new probes was established in animal experiments using rats and was shown to occur in vitro at pH 4-5. During incubation in human gastric juice, however, almost $30 \%$ ester cleavage by non-specific gastric esterases occurred within the first five minutes, thus further limiting the use of these compounds in determining endogenous nitrosation in hypoacidic patients.

$\mathrm{N}$-nitroso compounds are well known as potent carcinogens. ${ }^{1}$ They are widely distributed in the environment and can be detected in various foods for example, in nitrite treated meat and in beer, ${ }^{2}$ tobacco products, ${ }^{3}$ cosmetics, ${ }^{45}$ and in drugs. ${ }^{6}$ In

Address for correspondence: Dr G Eisenbrand, Department of Food Chemistry and Environmental Toxicology, University of Kaiserslautern, D6750 Kaiserslautern, Federal Republic of Germany.

Accepted for publication 19 December 1988. addition to exposure by those exogenous sources, endogenous formation of $\mathrm{N}$-nitroso compounds has been a matter of considerable concern. ' In laboratory animals endogenous nitrosation has already been shown more than 15 years ago. ${ }^{8}$ By measuring $\mathrm{N}$-nitrosated amino acids in the urine it has later been shown unequivocally, that endogenous nitrosation of such precursors occurs at substantial rates. ${ }^{90}$ The method had been developed by Ohshima and Bartsch ${ }^{9}$ for an assessment of endogenous nitrosation in man. 
Nitrite concentrations in the gastric fluid have been shown to be (directly) correlated with intragastric $\mathrm{pH} .{ }^{11}{ }^{12}$ Under conditions of hypochlorhydria, bacterial contamination of gastric juice is common and nitrate reducing microorganisms are regularly found. ${ }^{1314}$ The presence of raised nitrite concentrations is considered to favour the intragastric formation of $\mathrm{N}$-nitroso compounds under such conditions.

It has been reported that intragastric concentrations of $\mathrm{N}$-nitroso-compounds are enhanced in the anacidic $\mathrm{pH}$ - for example, in patients with Billroth II gastric resection ${ }^{15}$ and that a positive correlation between $\mathrm{pH}$ and $\mathrm{N}$-nitroso compound concentration was observed. ${ }^{116}$ Other authors have, however, not found such a correlation. ${ }^{17}$ Analytical problems to be faced with determination of total $\mathrm{N}$-nitrosocompounds in gastric juice may, at least in part, be responsible for these contradictory findings. They have been adequately reviewed by Pignatelli et al. ${ }^{16}$ In our earlier experiments we had analysed gastric juice before and after gavage of $200 \mathrm{mg}$ nitrate to investigate how various disorders of the upper gastrointestinal tract influence the intragastric concentration of nitrite. ${ }^{18}$ Three patient groups were found to have high nitrite formation rates in the gastric juice: gastric resection after Billroth I (BI) or Billroth II (BII) and chronic atrophic gastritis (CAG). These patient groups have now been increased to 12 subjects, and furthermore we have investigated the potential of endogenous formation of $\mathrm{N}$-nitroso compounds using proline as an indicator and monitoring the urinary excretion of nitrosoproline (NPRO). This N-nitroso compound is neither mutagenic nor carcinogenic. ${ }^{19-21}$ The disorders found in our experiments to favour nitrite formation after oral intake of nitrate have been shown to increase the risk for gastric cancer. Gastrointestinal disorders like CAG, BI and BII status being characterised by achlorhydric gastric fluid and bacterial growth in the stomach have been identified as precursor lesions for gastric cancer. ${ }^{22-25}$

The present investigation wanted to ascertain whether enhanced nitrite concentrations in the gastric fluid of patients having the described gastric disorders are liable to yield enhanced endogenous $\mathrm{N}$-nitrosation rates, as measured by urinary excretion of NPRO.

\section{Methods}

CHEMICALS

All chemicals were obtained from Merck (Darmstadt, FRG), Fluka (Neu-Ulm, FRG), or Janssen (Beerse, Belgium) and were of analytical grade.
NPRO and NPIC was synthesised according to the method of Hansen et al, ${ }^{26}$ their purity were checked by established methods. ${ }^{27}$ Ethereal diazomethane was prepared from $\mathrm{N}$-nitrosomethylurea and was redestilled before use.

\section{PATIENTS}

After diagnosis by gastroscopy and histological verification, 67 patients with various complaints of the upper gastrointestinal tract were classified into six groups: Billroth I (BI) or Billroth II (BII), proximalgastral vagotomy (PGV), chronic atrophic gastritis (CAG), ulcus ventriculi and ulcus duodeni. With the exception of the CAG group with only seven patients, each group consisted of 12 subjects; healthy, age matched volunteers served as controls.

For the NPRO-test, patients were selected from the BI, BII, and PGV-groups. As CAG patients were not available within this period we restricted our investigations to BI and BII (high nitrite groups) and PGV (low nitrite group).

The patients and healthy controls participating in this study had been given detailed information on the experimental procedure, its aim and its risks and had given their oral consent.

\section{GASTRIC JUICE}

After a $12 \mathrm{~h}$ fast, samples of gastric juice were collected by gastric tube aspiration before (time zero) and 30, 90, and $240 \mathrm{~min}$ after ingestion of $200 \mathrm{mg}$ nitrate in $50 \mathrm{ml}$ water. Immediately after delivery the samples were stabilised with $0.1 \mathrm{ml} 10 \mathrm{~N} \mathrm{NaOH}$ and analysed for nitrite using a continuous flow analyser. Nitrite was detected by diazotation with sulphanilamide and formation of a coloured azo compound by coupling with $\mathrm{N}-1$-naphthylethylenediammoniumdichloride. The concentration range was linear from $0 \cdot 1$ to $50 \mathrm{ppm} ; \lambda=540 \mathrm{~nm}$.

\section{NITROSOPROLINE TEST}

After $12 \mathrm{~h}$ overnight fasting, subjects first ingested $200 \mathrm{mg}$ nitrate in $50 \mathrm{ml}$ water and $30 \mathrm{~min}$ later $500 \mathrm{mg}$ of L-proline in $50 \mathrm{ml}$ water. No food or beverage was consumed for the next two hours. Urine was collected quantitatively over $24 \mathrm{~h}$ in 21 polyethylene bottles containing $17.6 \mathrm{~g}$ ascorbic acid to prevent artifact formation together with $400 \mathrm{mg}$ ethylmercurimercapto-benzoate as a preservative ${ }^{2 \times}$ The bottles were stored at $5^{\circ} \mathrm{C}$ until analysis. Food ingestion was recorded on the day of the experiment and on the day before. Smoked or cured products were not allowed to minimise intake of preformed NPRO. ${ }^{24}$

NPRO DETERMINATION

The total volume of the $24 \mathrm{~h}$ urine was measured. 
Aliquots of $15 \mathrm{ml}$ were taken for NPRO determination (double). After the addition of $500 \mu \mathrm{g}$ NPIC as an internal standard, the sample was deproteinised with $1 \mathrm{ml}$ each of potassium hexacyanoferrate II $\left(106 \mathrm{~g} \mathrm{~K}_{4} \mathrm{Fe}(\mathrm{CN})_{6} /\right.$ water $)$ and zinc sulphate $(220 \mathrm{~g}$ $\mathrm{ZnSO}_{4} / \mathrm{l}$ acetic acid, $3 \%$ ). After filtration through a glass fibre filter, the filtrate was saturated with $9 \mathrm{~g}$ ammonium sulphate. Sulphuric acid $(1 \mathrm{ml}, 50 \%)$ was added and the sample was transferred to a column of $13 \mathrm{~g}$ silica gel (Extrelut ${ }^{\mathrm{R}}$, Merck, Darmstadt, FRG) over $2 \mathrm{~g}$ anhydrous sodium sulphate. After $20 \mathrm{~min}$ equilibration the column was eluted with $60 \mathrm{ml}$ ethyl acetate. The eluate was evaporated in a rotary evaporator at $50^{\circ} \mathrm{C}$ to a final volume of about $1 \mathrm{ml}$. The concentrate was transferred to a $20 \mathrm{ml}$ reaction vial and an excess (normally $2 \mathrm{ml}$ ) of distilled ethereal diazomethane was added. After 15 min standing at room temperature the volume was reduced to $1 \mathrm{ml}$ by a gentle stream of nitrogen.

GC-ANALYSIS

Glass column: $\quad 1 \mathrm{~m} \times 2 \mathrm{~mm}$, packed with $3 \%$ Carbowax $20 \mathrm{M}$, TPA on Volaspher (100-120 mesh)

Carrier gas: helium, $30 \mathrm{ml} / \mathrm{min}$

Oven temperature: $130^{\circ} \mathrm{C}(4 \mathrm{~min})$ and programmed to $210^{\circ} \mathrm{C}$ at $4^{\circ} \mathrm{min}$

Detector: TEA, model 502 (Thermo Electron, Waltham, MA, USA)

Recovery of NPRO was $79 \%(\mathrm{SD}=6 \cdot 8, \mathrm{n}=6)$ and of the internal standard NPIC $92 \%(\mathrm{SD}=6 \cdot 8, \mathrm{n}=6)$; detection limit of NPRO was $0.5 \mathrm{ppb}$.

IN VITRO NITROSATION OF PROLINE AND PROLINE ESTERS

Solutions of proline or proline ester and nitrite (50 $\mathrm{mM}$ each) were incubated at $37^{\circ} \mathrm{C}$ for $60 \mathrm{~min}$ in citrate buffer $(20 \mathrm{ml}, \mathrm{pH} \mathrm{2-6)}$. Yields of $\mathrm{N}$-nitroso products were determined spectrometrically at $320-400 \mathrm{~nm}$ against solvent blanks (Lambda 5, recording spectrophotometer, Perkin Elmer, Überlingen, FRG).

Table 1 Nitrite concentration (ppm) in fasting gastric juice of various patient groups and healthy controls; median with $95 \%$ confidence interval, minimum and maximum values

\begin{tabular}{lllrr}
\hline Group & Median & $95 \%$ Confrange & Min & Max \\
\hline Controls & 0.4 & ND-0.7 & ND & $4 \cdot 9$ \\
BI & $1 \cdot 5$ & $0 \cdot 5-1 \cdot 9$ & $0 \cdot 1$ & $3 \cdot 4$ \\
BII & $2 \cdot 0$ & $0 \cdot 8-6 \cdot 0$ & $0 \cdot 8$ & $18 \cdot 3$ \\
CAG & $1 \cdot 3$ & $0 \cdot 3-4 \cdot 4$ & $0 \cdot 8$ & $4 \cdot 4$ \\
PGV & 0.7 & $0 \cdot 2-2 \cdot 1$ & ND & $9 \cdot 0$ \\
Ulc ventr & 0.2 & $0 \cdot 1-0 \cdot 5$ & ND & $0 \cdot 5$ \\
Ulc duod & 0.3 & $0 \cdot 1-0.4$ & ND & $0 \cdot 5$ \\
\hline
\end{tabular}

$t=0$, fasting gastric juice
Table 2 Nitrite concentration (ppm) in gastric juice of various patient groups and healthy controls; 30 min after oral intake of $200 \mathrm{mg}$ nitrate, median with $95 \%$ confidence interval, minimum and maximum values

\begin{tabular}{lclrr}
\hline Group & Median & $95 \%$ Confrange & Min & Max \\
\hline Controls & $1 \cdot 4$ & $0 \cdot 2-3 \cdot 5$ & $0 \cdot 2$ & $9 \cdot 1$ \\
BI & $7 \cdot 5$ & $3 \cdot 0-19 \cdot 0$ & $1 \cdot 3$ & $30 \cdot 0$ \\
BII & $14 \cdot 1$ & $4 \cdot 6-24 \cdot 2$ & $3 \cdot 8$ & $93 \cdot 4$ \\
CAG & $10 \cdot 6$ & $0 \cdot 4-86 \cdot 1$ & $0 \cdot 4$ & $86 \cdot 1$ \\
PGV & $2 \cdot 8$ & $0 \cdot 8-7 \cdot 1$ & $0 \cdot 2$ & $21 \cdot 2$ \\
Ulc ventr & $0 \cdot 9$ & $0 \cdot 7-2 \cdot 7$ & ND & $11 \cdot 3$ \\
Ulc duod & $0 \cdot 4$ & $0 \cdot 2-1 \cdot 2$ & $0 \cdot 1$ & $2 \cdot 2$ \\
\hline
\end{tabular}

$\mathrm{t}=30 \mathrm{~min}$.

CIEAVAGE OF PROLINE METHYLESTER IN GASTRIC JUICE

Proline methyl ester $(100 \mu \mathrm{M})$ was incubated at $37^{\circ} \mathrm{C}$ for $5,10,30$, or $60 \mathrm{~min}$ in $1 \mathrm{ml}$ human gastric juice (pH 1.5). After nitrosation with sodium nitrite $(10 \mathrm{mg} / \mathrm{ml}$ water) the solution was saturated with ammonium sulphate and extracted at $\mathrm{pH}$ 8-9 $(\mathrm{NaOH}, 1 \mathrm{~N})$ with $3 \times 1 \mathrm{ml}$ ethyl acetate to isolate NPRO-methyl ester. The aqueous phase was acidified to $\mathrm{pH} 1-2(\mathrm{HCl}, 1 \mathrm{~N})$ and extracted with $3 \times 1 \mathrm{ml}$ ethyl acetate to isolate NPRO. After methylation with diazomethane, samples were analysed as described for urine samples.

CLEAVAGE OF NITROSATED PROLINE ESTERS

WITH NON-SPECIFIC ESTERASES

To measure cleavage by non-specific esterases, NPRO methyl or -ethyl ester $(5 \mathrm{ml}$ of a $10 \mathrm{or} 100 \mu \mathrm{g} /$ $\mathrm{ml}$ solution in phosphate buffer) in first experiments were incubated with esterase $(10 \mu \mathrm{l})$ from porcine liver (suspension: $3 \mathrm{mg} / \mathrm{ml}$; Boehringer, Mannheim, FRG). Furthermore NPRO methyl or -ethyl ester $(0.2 \mathrm{ml}$ of a $0.5 \mathrm{mg} / \mathrm{ml}$ solution in phosphate buffer $)$ were incubated in rat serum $(9.8 \mathrm{ml}$, male SD rats, protein: $52 \mathrm{mg} / \mathrm{ml})$. Aliquots $(1 \mathrm{ml})$ were taken at

Table 3 Nitrite concentration (ppm) in gastric juice of various patient groups and healthy controls; 90 min after oral intake of $200 \mathrm{mg}$ nitrate, median with $95 \%$ confidence interval, minimum and maximum values

\begin{tabular}{lcccr}
\hline Group & Median & $95 \%$ Conf range & Min & Max \\
\hline Controls & $1 \cdot 6$ & $0 \cdot 7-2 \cdot 2$ & $0 \cdot 5$ & $5 \cdot 8$ \\
BI & $7 \cdot 0$ & $3 \cdot 2-35 \cdot 0$ & $2 \cdot 8$ & $50 \cdot 0$ \\
BII & $20 \cdot 9$ & $13 \cdot 3-36 \cdot 7$ & $8 \cdot 8$ & $157 \cdot 7$ \\
CAG & $12 \cdot 6$ & $1 \cdot 0-29 \cdot 2$ & $1 \cdot 0$ & $29 \cdot 2$ \\
PGV & $1 \cdot 3$ & $0 \cdot 6-8 \cdot 3$ & $0 \cdot 3$ & $38 \cdot 0$ \\
Ulc ventr & $3 \cdot 1$ & $1 \cdot 1-4 \cdot 6$ & $1 \cdot 0$ & $27 \cdot 5$ \\
Ulc duod & $0 \cdot 3$ & $0 \cdot 1-0 \cdot 6$ & ND & $3 \cdot 0$ \\
\hline
\end{tabular}

$\mathrm{t}=90 \mathrm{~min}$. 
Table 4 Nitrite concentration (ppm) in gastric juice of various patient groups and healthy controls; 240 min after oral intake of $200 \mathrm{mg}$ nitrate, median with $95 \%$ confidence interval, minimum and maximum values

\begin{tabular}{lcllr}
\hline Group & Median & $95 \%$ Conf range & Min & Max \\
\hline Controls & $0 \cdot 7$ & $0 \cdot 2-3 \cdot 1$ & $0 \cdot 2$ & $3 \cdot 2$ \\
BI & $5 \cdot 9$ & $5 \cdot 0-9 \cdot 2$ & $4 \cdot 1$ & $24 \cdot 2$ \\
BII & $13 \cdot 0$ & $8 \cdot 3-32 \cdot 7$ & $0 \cdot 5$ & $200 \cdot 2$ \\
CAG & $9 \cdot 7$ & $1 \cdot 5-40 \cdot 0$ & $1 \cdot 5$ & $40 \cdot 0$ \\
PGV & $0 \cdot 9$ & $0 \cdot 6-10 \cdot 4$ & $0 \cdot 4$ & $30 \cdot 0$ \\
Ulc ventr & $1 \cdot 8$ & $0 \cdot 5-11 \cdot 6$ & $0 \cdot 3$ & $16 \cdot 1$ \\
Ulc duod & $0 \cdot 3$ & $0 \cdot 1-2 \cdot 9$ & ND & $4 \cdot 3$ \\
\hline
\end{tabular}

$\mathrm{t}=240 \mathrm{~min}$.

specific time points up to $15 \mathrm{~min}$, extracted with dichloromethane $(3 \times 1 \mathrm{ml})$ and analysed by GC-TEA as described.

ANIMAL EXPERIMENTS

Male SD rats, 200-250 g (Charles River Wiga, Sulzfeld, FRG), were kept in a $12 \mathrm{~h}$ light/dark cycle. They received standard pelleted diet (Altromin, Lage, FRG) and tap water ad libitum. Food was withdrawn $12 \mathrm{~h}$ before start of the experiment.

\section{EXPERIMENTS WITH LABELLED COMPOUNDS}

To study excretion rate of NPRO after ingestion of NPRO methyl or ethylesters, [U- $\left.{ }^{14} \mathrm{C}\right]$ labelled $\mathrm{N}$-nitrosoproline esters $(10,20$, or $40 \mathrm{mg} / \mathrm{kg} ; 250 \mathrm{mCi} /$ $\mathrm{mM}=9.25 \mathrm{GBq} / \mathrm{mM}$ ) were applied by gavage to rats. A first experiment had shown that exhalation of ${ }^{14} \mathrm{CO}_{2}$ accounted for less than $0.5 \%$ of total radioactivity excreted. Therefore normal metabolism cages were used. Animals were placed individually into these cages, urine was collected for $2 \times 24 \mathrm{~h}$ and was preserved as described. Radioactivity was deter-

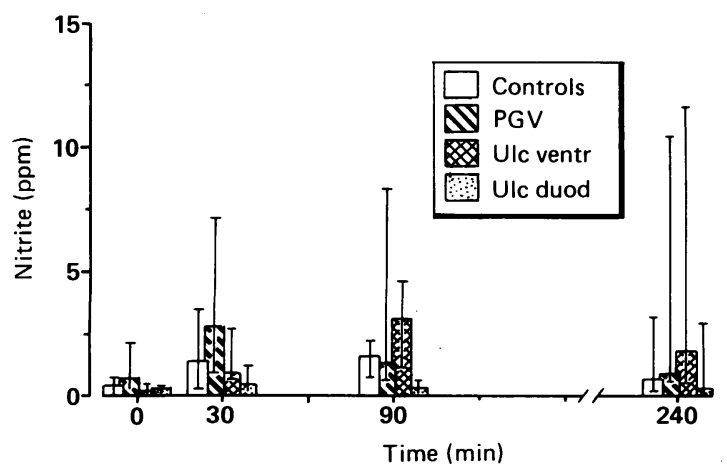

Fig. 1 Nitrite concentration in gastric juice after oral intake of $200 \mathrm{mg}$ nitrate, time course of median with $95 \%$ confidence intervals; low nitrite groups.

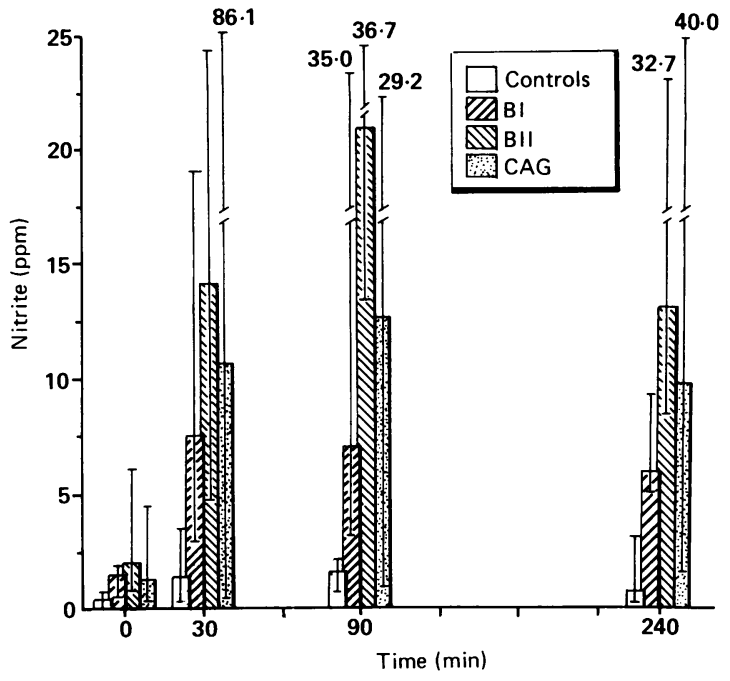

Fig. 2 Nitrite concentration in gastric juice after oral intake of $200 \mathrm{mg}$ nitrate, time course of median with $95 \%$ confidence intervals; high nitrite groups.

mined with a liquid-scintillation-counter (Mark III, Searle, Illinois, USA).

\section{ENDOGENOUS NITROSATION OF PROLINE} METHYLESTER IN RATS

Rats received between 5 and $35 \mu \mathrm{mol}$ proline methylester in $0.5 \mathrm{ml}$ citrate buffer $(\mathrm{pH} 3,0.1 \mathrm{M})$ by gavage. Immediately thereafter, $0.5 \mathrm{ml}$ sodium nitrite $(20 \mu \mathrm{M})$ was applied. Animals were placed individually into metabolism cages, urine was collected for $24 \mathrm{~h}$ and was further processed as described.

\section{Results}

NITRITE IN GASTRIC JUICE

Median intragastric nitrite concentrations at sampling times specified together with their 95\% confidence intervals are shown in Tables $1-4$ and Figures 1, 2.

Differences in gastric nitrite concentrations can readily be seen already in fasting gastric juice of the various patient groups. Those known to have low $\mathrm{pH}$ values (controls, PGV, ulcus ventriculi and ulcus duodeni) showed median values up to $0.7 \mathrm{ppm}$ nitrite in their gastric fluids. Billroth and CAG patients however, whose gastric juice has been established to be less acidic to neutral, had 1.3-2.0 ppm nitrite in their fasting gastric fluids.

After ingestion of nitrate, however, differences in the potential to form nitrite become much more 
Table 5 Total amounts of NPRO excreted in the $24 \mathrm{~h}$ urine of humans after oral gavage of $200 \mathrm{mg}$ of nitrate and $500 \mathrm{mg}$ of proline, arranged according to their distribution in the different range subgroups ( $\mu \mathrm{g} N P R O / 24 \mathrm{~h}$ urine volume)

\begin{tabular}{|c|c|c|c|c|c|c|c|c|c|}
\hline \multirow{2}{*}{\multicolumn{2}{|c|}{$\begin{array}{l}\text { NPRO-concentration } \\
\text { subgroups }\end{array}$}} & \multicolumn{2}{|c|}{ Healthy controls } & \multicolumn{2}{|c|}{ Billroth I } & \multicolumn{2}{|c|}{ Billroth II } & \multicolumn{2}{|c|}{$P G V$} \\
\hline & & $n$ & $\mu g N P R O$ & $n$ & $\mu g N P R O$ & $n$ & $\mu g N P R O$ & $n$ & $\mu g N P R O$ \\
\hline (a) & $\mathrm{ND}^{*}-1 \mu \mathrm{g}$ & 3 & ND & 5 & ND & 21 & ND & 1 & ND \\
\hline (b) & $1 \cdot 1-5 \mu \mathrm{g}$ & 3 & $4 \cdot 2 ; 2 \cdot 4 ; 2 \cdot 1$ & - & - & 1 & 1.7 & 1 & 4.9 \\
\hline (c) & $5 \cdot 1-10 \mu \mathrm{g}$ & 10 & $\begin{array}{c}7 \cdot 6 ; 6 \cdot 3 ; 6 \cdot 7 ; 7 \cdot 4 \\
8 \cdot 0 ; 8 \cdot 4 ; 5 \cdot 9 \\
6 \cdot 2 ; 6 \cdot 2 ; 5 \cdot 3\end{array}$ & - & - & 4 & $7 \cdot 8 ; 9 \cdot 3 ; 5 \cdot 4 ; 5 \cdot 9$ & 1 & $7 \cdot 6$ \\
\hline (d) & $<10 \mu g$ & 6 & $\begin{array}{l}11 \cdot 4 ; 18 \cdot 2 ; 12 \cdot 3 ; \\
33 \cdot 5 ; 20 \cdot 4 ; 13 \cdot 9\end{array}$ & - & - & - & - & 3 & $15 \cdot 3 ; 12 \cdot 4 ; 22 \cdot 9$ \\
\hline
\end{tabular}

*ND: $<0 \cdot 5 \mathrm{ppb}$ (detection limit).

evident. Healthy controls had median gastric nitrite concentrations that remained throughout the sampling period in a low concentration range $(\leq 1.6$ $\mathrm{ppm})$. The same was true for the ulcus- and PGVpatients, who showed nitrite concentrations not significantly different from those of healthy controls (Wilcoxon's rank-sum test). In contrast with these groups, Billroth and CAG patients were found to build up much higher nitrite concentrations. In some cases very high values (up to $200 \mathrm{ppm}$ ) were measured.

\section{NITROSATION OF PROLINE IN THE STOMACH} Results are shown in Table 5 and Figure 3.

As can be seen, highest amounts of NPRO were found in the urine of healthy control persons with values up to about $34 \mu \mathrm{g}$ NPRO (19/22 positives). Likewise, in PGV patients an almost identical frequency distribution was found (five of six positives). In contrast, the urines of BI and BII patients, proven to have high nitrite values in gastric juice were practically devoid of measurable NPRO concentrations (five of five BI and 21/26 BII negatives).

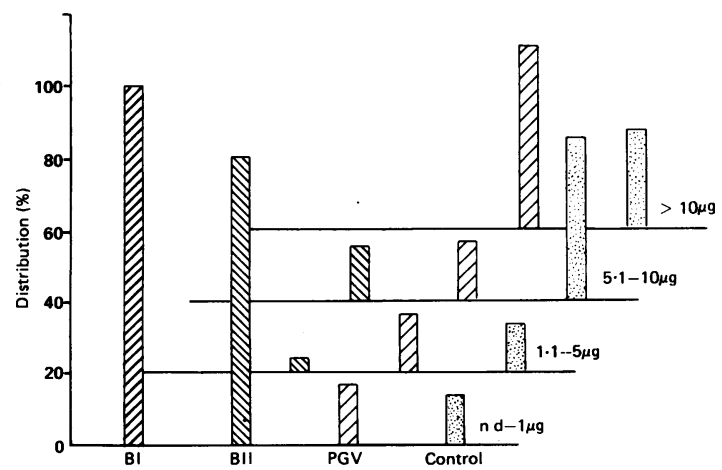

Fig. 3 Frequency distribution of NPRO amounts, excreted in 24 h urine.
IN VITRO NITROSATION KINETICS

Results of in vitro nitrosation of proline at different $\mathrm{pH}$-values compared with nitrosation of proline methyl- and ethyl ester are shown in Figure 4. As can be seen, the free amino acid is nitrosated at substantial rates only at $\mathrm{pH}$ values $<4$. In contrast, the esters still undergo appreciable nitrosation at $\mathrm{pH} 4-5$.

\section{CLEAVAGE OF PROLINE METHYL ESTER IN}

HUMAN GASTRIC JUICE

On incubation of proline methyl ester in gastric juice, $30-40 \%$ of the compound decomposed within five minutes (first sampling time). Further incubation, however, did not result in further decomposition.

\section{CLEAVAGE OF NITROSOPROLINE ESTERS BY}

NON-S PECIFIC ESTERASES

NPRO ethyl ester was hydrolysed about twice as fast as NPRO methyl ester. In rat serum half-life of 6.4 $0 \cdot 8 \pm \min$ for the ethyl and of $13 \cdot 11.5 \pm$ min for the methyl- ester (each $10 \mu \mathrm{g}$ ester/ml .serum) were found. In heat denaturated serum $\left(90^{\circ} \mathrm{C}\right.$ for $\left.10 \mathrm{~min}\right)$ no decomposition was observed within one hour.

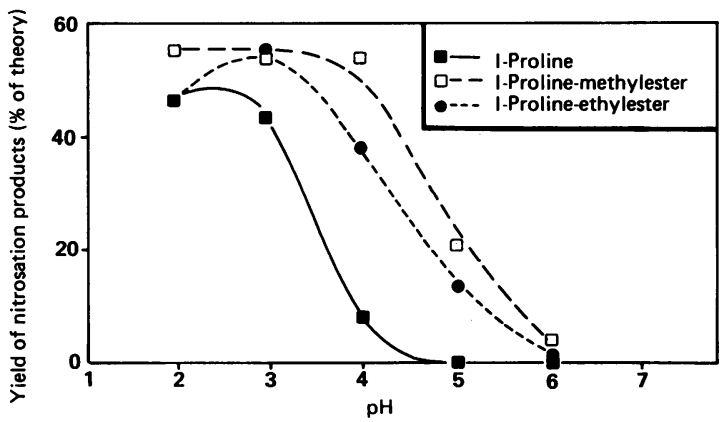

Fig. 4 In vitro nitrosation of proline and its methyl-and ethyl ester as a function of $\mathrm{pH}(c=50 \mathrm{mmol}, t=60 \mathrm{~min}$, $T=37^{\circ} \mathrm{C}$ ). 
EXCRETION EXPERIMENTS WITH ${ }^{1+}$ C-IABELIED NPRO ESTERS

Within $24 \mathrm{~h}$, radioactivity was quantitatively excreted as NPRO in the urine. No intact nitrosoproline ester could be detected.

ENDOGENOUS NITROSATION OF PROLINE

METHYL ESTER IN RATS

Gavage of 5-35 $\mu \mathrm{mol}$ proline methyl ester together with $10 \mu \mathrm{mol}$ sodium nitrite led to the excretion of 25-130 nmol NPRO in the $24 \mathrm{~h}$ urine. A clear linear correlation between amounts of proline methyl ester applied and amounts of NPRO excreted could not be established.

\section{Discussion}

The relevance of endogenously formed $\mathrm{N}$-nitroso compounds for human cancer induction has been controversely discussed over several years. ${ }^{31-32}$ This continuing discussion has clearly shown the need to obtain reliable data on amounts of $\mathrm{N}$-nitroso compounds synthesised under various conditions within man's gastrointestinal tract. We started our experiments analysing human gastric juice for nitrite as the most important precursor compound. Samples were taken from patients with distinct lesions of the stomach or the duodenum, from patients who had undergone gastric surgery (BI, BII, and PGV) and from healthy controls. To study how nitrate (mainly supplied by vegetables) influences the intragastric nitrite level, gastric fluid had been taken immediately before and at three time points after gavage of $200 \mathrm{mg}$ nitrate in $50 \mathrm{ml}$ water.

The results confirmed earlier findings ${ }^{1>}$ and those of others ${ }^{32}$ obtained without previous nitrate loading. Fasting gastric fluids of patients with BI, BII, and CAG status contain significantly higher nitrite concentrations than those from healthy controls. After nitrate ingestion groups with higher basal nitrite values responded with a very much higher nitrite formation in their gastric juice than the groups with low basal nitrite concentrations. Patients with ulcus ventriculi or duodeni and $\mathrm{PGV}$ patients were not significantly different in their nitrite values from healthy controls (Fig. 1).

Gastric fluid from BI-, BII-, and CAG-patients in most cases contains large numbers of microorganisms, including nitrate-reducing species. ${ }^{1+34,35}$ These conditions in the stomach of BI-, BII-, and CAG-patients are expected to cause an increased synthesis of $\mathrm{N}$-nitroso compounds. ${ }^{1.3}$ We tried to quantify this endogenous nitrosation potential by means of the NPRO test. The results of this study show that NPRO formation is higher in the low nitrite groups with normacidic $\mathrm{pH}$ of gastric fluid than in the high nitrite groups, characterised by hypoacidic gastric conditions.

Our studies and those of others ${ }^{3 n}$ on nitrosation kinetics have shown that proline is nitrosated at measurable rates only at $\mathrm{pH}$ values $<4$. Under conditions approaching neutrality, however, proline is not nitrosated to a measurable extent, in spite of high to very high nitrite concentrations in the stomach. For Billroth-patients, in addition to the high gastric $\mathrm{pH}$ the shorter passage time through the gastric stump might also contribute to lower nitrosation yields.

The results clearly show that proline is not a suitable indicator compound for evaluation of endogenous nitrosation potential in the gastrointestinal tract of patients with hypoacidic gastric conditions. The search for more appropriate chemical probes to measure in vivo nitrosation is therefore of utmost importance for the assessment of the possible human health risk originating from endogenous nitrosation. Our findings on nitrosation of proline esters show that some shift towards the neutral $\mathrm{pH}$ range can be achieved by using proline esters as chemical probes. As appreciable nitrosation occurs only at pH 5, however, this is still not sufficient. The rapid cleavage of proline esters observed in gastric juice also argues against their potential use as nitrosation probes.

Recent data on catalysis of nitrosation by certain bacteria at neutral $\mathrm{pH}$ are most relevant.$^{37}$ These data have shown that in the presence of such bacteria certain secondary amines, especially morpholine, piperidine, and pyrrolidine are nitrosated under near physiological conditions at neutral $\mathrm{pH}$. These data again stress the need to develop chemical probes that are able to detect in vivo nitrosation potential in the human gastrointestinal tract at near neutral $\mathrm{pH}$.

\section{References}

1 Druckrey H, Preußmann R, Ivankovic S, Schmähl D. Organotrope carcinogene Wirkungen bei 6.5 verschiedenen N-Nitroso-Verbindungen an BD-Ratten. Z Krebsforsch 1967; 69: 103-201.

2 Preußmann R, Spiegelhalder B, Eisenbrand G, Janzowski C. N-nitroso compounds in food. In: Naturally occurring carcinogens - mutagens and modulators of carcinogenesis. Japan Sci Soc Press, Tokyo; Univ Park Press, Baltimore, 1979: 185-94.

3 Hoffmann D, Brunnemann KD, Adams JD, Hecht SS. Formation and analysis of nitrosamines in tobacco products and their endogenous formation in tobacco consumers. In: O’Neill IK, von Borstel RC, Miller CT, Long $\mathrm{J}$, Bartsch $\mathrm{H}$, eds. $\mathrm{N}$-nitroso compounds: occurrence, biological effects and relevance to human cancer. Lyon: International Agency for Research on Cancer, Sci Publ No 57, 1984: 313-8. 
4 Spiegelhalder B, Preußmann R. Contamination of toiletries and cosmetic products with volatile and nonvolatile N-nitroso carcinogens. J Cancer Res Clin Oncol 1984; 108: 160-3.

5 Sommer H, Eisenbrand G. A method for determination of $\mathrm{N}$-nitroso-alkanolamines in cosmetics. Z Lebensm Unters Forsch 1988; 186: 235-8.

6 Eisenbrand G, Spiegelhalder B, Kann J, Klein R, Preußmann R. Carcinogenic N-nitrosodimethylamine as a contamination in drugs containing 4-dimethylamino-2,3-dimethyl-1-phenyl-3-pyrazolin-5one (Amidopyrine, Aminophenazone). Arzneimittel forschung 1979; 29: 867-9.

7 Tannenbaum SR. Endogenous formation of N-nitroso compounds: a current perspective. In: Bartsch $\mathrm{H}$, O'Neill I, Schulte-Hermann R, eds. Relevance of $N$-nitroso compounds to human cancer: exposures and mechanisms. Lyon: IARC Sci Publ No 84, 1987: 396-9.

8 Sander J, Bürkle G. Induktion maligner Tumoren bei Ratten durch gleichzeitige Verfütterung von Nitrit und sekundären Aminen. Z Krebsforsch 1969; 73: 54-66.

9 Ohshima H, Bartsch H. Quantitative estimation of endogenous nitrosation reaction in man by monitoring $\mathrm{N}$-nitrosoproline excreted in the urine. Cancer Res 1981; 41: 3658-62.

10 Tricker A, Preußmann R. Influence of cysteine and nitrate on the endogenous formation of $\mathrm{N}$-nitrosamino acids. Cancer Lett 1987; 34: 39-47.

11 Reed PI, Summers K. Smith PL, et al. Effect of ascorbic acid treatment on gastric juice nitrite and $\mathrm{N}$-nitroso compound concentrations in achlorhydric subjects. Gut 1983; 24: 492-3.

12 Caygill CP, Leach SA, Kirkham JS, Northfield TC, Hall $\mathrm{CN}$, Hill MJ. Gastric hypoacidity as a risk factor for gastric and other cancers. In: Bartsch H, O'Neill I, Schulte-Hermann R, eds. Relevance of N-nitroso compounds to human cancer: exposures and mechanisms. Lyon: IARC Sci Publ No 84, 1987: 524-6.

13 Calmels S, Ohshima H, Crespi M, Leclerc H, Cattoen C, Bartsch $\mathrm{H}$. N-nitrosamine formation by microorganisms isolated from human gastric juice and urine: biochemical studies on bacteria-catalysed nitrosation. In: Bartsch H, O'Neill I, Schulte-Hermann R, eds. Relevance of $\mathrm{N}$-nitroso compounds to human cancer: exposures and mechanisms. Lyon: IARC Sci Publ No 84 , 1987: 391-5.

14 Crespi M, Ohshima H, Ramazzotti V, et al. Intragastric nitrosation and precancerous lesions of the gastrointestinal tract: testing of an etiological hypothesis. In: Bartsch H, O'Neill I, Schulte-Hermann R, eds. Relevance of N-nitroso compounds to human cancer: exposures and mechanisms. Lyon: IARC Sci Publ No 84. 1987: 511-7.

15 Schlag P, Böckler R, Ulrich H, Peter M, Merkle P, Herfarth $\mathrm{C}$. Are nitrite and $\mathrm{N}$-nitroso compounds in gastric juice risk factors for carcinoma in the operated stomach? Lancet 1980; i: 727-9.

16 Pignatelli B, Richard I, Bourgade MC, Bartsch H. An improved method for analysis of total $\mathrm{N}$-nitroso compounds in gastric juice. In: Bartsch $\mathrm{H}$, O'Neill I, Schulte-Hermann R, eds. Relevance of N-nitroso com- pounds to human cancer: exposures and mechanisms. Lyon: IARC Sci Publ No 84, 1987: 209-15.

17 Keighley MR, Youngs D, Poxon V, et al. Intragastric Nnitrosation is unlikely responsible for gastric carcinoma developing after operations for duodenal ulcer. Gut 1984; 25: 238-45.

18 Eisenbrand G, Adam B, Peter M, Malfertheiner P, Schlag $P$. Formation of nitrite in gastric juice of patients with various gastric disorders after ingestion of a standard dose of nitrate - a possible risk factor in gastric carcinogenesis. In: O'Neill IK, von Borstel RC. Miller CT, Long J, Bartsch $\mathrm{H}$, eds. N-nitroso compounds: occurrence, biological effects and relevance to human cancer. Lyon: IARC Sci Publ No 57, 1984: 963-8.

19 Greenblatt M, Lijinsky W. Failure to induce tumors in Swiss mice after concurrent administration of amino acids and sodium nitrite. $J$ Natl Cancer Inst 1972; 48: 1389-92.

20 Garcia H, Lijinsky W. Studies of the tumorigenic effect in feeding of nitrosamino acids and of low doses of amines and nitrite to rats. Z Krebsforsch 1973; 78: $141-4$.

21 Magee PN, Chu CK, Gombar CT, Jensen DE, Parchman LG. Interaction of reactive intermediates with DNA. In: Snyder R, et al, eds. Biological reactive intermediates II B New York: Plenum Press, 1981: 1335-47.

22 Correa P, Haenszel W, Cuello C, Tannenbaum SR. Archer M. A model for gastric cancer epidemiology. Lancet 1975; ii: 58-60.

23 Dahm K, Eichen R, Mitschke H. Das Krebsrisiko im Restmagen. Zur Bedeutung des duodenogastrischen Refluxes bei verschiedenen gastroenteralen Anastomosen. Langenbecks Arch Chir 1977; 344: 71-82.

24 Correa P. Precursors of gastric and esophageal cancer. Cancer 1982; 50: 2554-65.

25 Bocckler RM, Meyer HW, Schlag P. An experimental study on bacterial colonisation and nitrite and nitrosamine production in the operated stomach. $J$ Cancer Res Clin Oncol 1983; 105: 62-6.

26 Hansen T, Iwaoka WT, Archer MC. A high-yield synthesis of ${ }^{1+} \mathrm{C}$-labelled nitrosoproline and nitrososarcosine. J Labelled Compounds 1974; 10: 689-93.

27 Lijinsky W, Keefer L, Loo J. The preparation and properties of some nitrosamino acids. Tetrahedron Lett 1970; 26: 5137-53.

28 Adam B. University of Hohenheim, FRG, 1987, Thesis.

29 Janzowsky C, Eisenbrand G, Preußmann R. Occurrence of $\mathrm{N}$-nitrosamino acids in cured meat products and their effect on formation of $\mathrm{N}$-nitrosamines during heating. Food Cosmet Toxicol 1978; 16: 343-8.

30 Tannenbaum SR, Sinskey AJ, Weisman M, Bishop W. Nitrite in human saliva. Its possible relationship to nitrosamine formation. $J$ Natl Cancer Inst 1974; 53: 7984.

31 Mirvish SS. The etiology of gastric cancer: intragastric nitrosamide formation and other theories. J Natl Cancer Inst 1983; 71: 631-47.

32 Ruddell WSJ, Bone ES, Hill MJ, Walters CL. Pathogenesis of gastric cancer in pernicious anaemia. Lancet 1978; i: 521-3.

33 Reed PJ, Smith PL, Haines K, House FR, Walters CL. 
Gastric juice N-nitrosamines in health and gastroduodenal disease. Lancet 1981; ii: 550-2.

34 Hehl G. University of Ulm. FRG. 1982. Thesis.

35 Reed PJ, Smith PL. Summers K, et al. The influence of enterogastric reflux on gastric juice bacterial growth. nitrite and $\mathrm{N}$-nitroso compound concentrations following gastric surgery. Scand J Gastroenterol 1984; 19 [suppl 92]: $232-4$.

36 Ohshima H, O’Neill IK, Friesen M, Béréziat JC, Bartsch H. Occurrence in human urine of new sulphur- containing $\mathrm{N}$-nitrosamino acids $\mathrm{N}$-nitrosothiazolidine-4carboxylic acid and its 2-methyl derivative and their formation. J Cancer Res Clin Oncol 1984: 108: 121-7.

37 Lcach SA, Cook AR. Challis BC. Hill MJ. Thompson $\mathrm{MH}$. Bacterially mediated $\mathrm{N}$-nitrosation reactions and endogenous formation of $\mathrm{N}$-nitroso compounds. In: Bartsch H, O'Neill I, Schulte-Hermann R, eds. Relevance of $N$-nitroso compounds to human cancer: exposures and mechanisms. Lyon: IARC Sci Publ No 84. 1987: 396-9. 